\title{
Multivariate analysis of heat tolerance characteristics in Santa Inês and crossbred lambs in the Federal District of Brazil
}

\author{
Marilma Pachêco Chediak Correa • \\ Bruno Stéfano Lima Dallago - Samuel Rezende Paiva • \\ Maria Eugênia Andrighetto Canozzi • \\ Helder Louvandini • Júlio Jardim Barcellos • \\ Concepta McManus
}

Accepted: 7 February 2013 / Published online: 1 March 2013

(C) Springer Science+Business Media Dordrecht 2013

\begin{abstract}
Heat tolerance is an important trait for deciding on which genetic resource to use on farms in tropical regions. Three genetic groups of lambs were evaluated by physical and physiological parameters related to adaptation and multivariate analyses used to test if these traits were efficient in separating the genetic groups and which traits were more important in this separation. Crossbred lambs were more similar to each other than to Santa Inês, in general; but individually there was an overlap between Ile de France and Santa Inês lambs. Size traits had higher canonical correlation with physiological variables, while rectal temperature, heart rate, and hemoglobin were more highly correlated with physical traits. Error rates using only
\end{abstract}

\section{P. C. Correa}

Escola de Veterinária, Universidade Federal de Goiás,

Campus Samambaia, Caixa postal 131, 74001-970,

Goiânia, GO, Brazil

e-mail: marilmazoo@gmail.com

\section{P. C. Correa}

Universidade Católica de Goiás,

Campus II-Av. Engler s/n Jardim Mariliza, 86, 74605-010,

Goiânia, GO, Brazil

B. S. L. Dallago $(\varangle) \cdot$ H. Louvandini $\cdot$ C. McManus

Pós-graduação em Ciências Animais, Universidade de Brasília, 70910-900, Brasília, DF, Brazil

e-mail: dallago@unb.br

\section{H. Louvandini}

e-mail: louvandini@cena.usp.br

C. McManus

e-mail: concepta.mcmanus@ufrgs.br physiological traits were high, suggesting that these are inefficient in separating groups of lambs for heat tolerance, while separation with physical traits was more efficient.

Keywords Adaptation $\cdot$ Sheep $\cdot$ Statistical methods · Thermolysis $\cdot$ Temperature

\section{Introduction}

The sheep industry in Brazil has expanded rapidly especially in the Midwest region. Although the numbers are small,

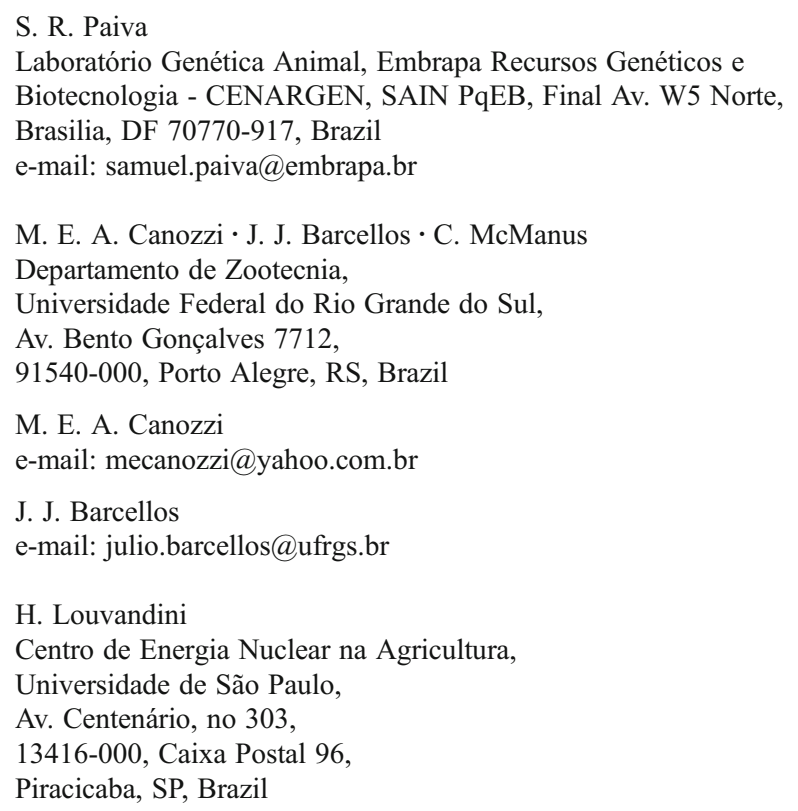


accounting for about $6.7 \%$ of the national herd (ANUALPEC 2012), this region shows the highest growth rate in the country. Crossbreeding is becoming more popular as farmers wish to produce lambs with higher growth rates and better carcass composition than the better adapted hair sheep breeds such as Santa Inês (McManus et al. 2010). There are a few studies concerning the adaptation of different sheep ecotypes (wool or hair) in this region, which is characterized by savannah-type forage with high mean daily temperatures and low humidity (McManus et al. 2011b).

The thermal environment for sheep is an important factor to be considered in determining optimal management strategies and therefore needs detailed study (McManus et al. 2011a), especially in regions where little information is available. Thus, the characterization of the climate and the study of reactions of sheep to heat stress should be identified for indicating the best management practices, appropriate design of facilities, and nutrition plan so that animals can adequately express production potentials.

In a tropical environment, where animals cannot balance the amount of heat gained during the warm periods of the day, there will be heat stress, with increased secretion of cortisol, a hormone that controls a series of metabolic (Starling et al. 2005), and behavioral changes, such as reductions in food intake and digestion (Silanikove 2000) leading to changes in production (Neiva et al. 2004) and reproduction (Marai et al. 2007).

In a study evaluating the effect of environmental stress on productive and physiological parameters of Santa Inês sheep, Neiva et al. (2004) observed that the elevation of temperature in the afternoon increased rectal temperature and respiratory rate. However, adaptability should not be assessed only by these traits as several factors interfere in the process of adaptation of animals. Other tests should be applied to determine more precisely the adaptation of animals in various aspects, such as physiological, productive, and reproductive analyses (McManus et al. 2008).

As several traits can change with stress and therefore influence productivity, these should be analyzed together and not in an isolated manner. There are several multivariate statistical techniques that can be used in studies of genetic divergence, such as cluster, principal components, and discriminant analysis, which provide useful information for the evaluation of animal production systems (Dias et al. 1997). Selection of the most appropriate analysis depends on the desired accuracy, ease of analysis and how the data were obtained (Ferreira et al. 2003). Other studies have been performed to separate genetic groups due to their heat tolerance and see which traits are useful in this separation (Castanheira et al. 2010a, b).

The objective of this study was to carry out a multivariate analysis of physical and physiological traits related to heat in Santa Inês lambs and their cross breeds in the Federal District of Brazil.

\section{Material and methods}

The experiment (approved by the University Ethics Committee - 33/2009) was carried out in the Sheep Management Center on the Água Limpa Experimental farm (FAL) of the Universidade de Brasília (UnB), $15^{\circ} 47^{\prime}$ latitude South and $47^{\circ} 56^{\prime}$ longitude West Gr, Distrito Federal, Brazil. The climate type is Aw using the Köppen classification.

The environment (Table 1) was characterized using the following measurements: temperatures of black globe (TBG) on the three days of the experiment, as well as dry (TDB) and wet (TWB) bulbs using a ventilated psychrometer positioned approximately $0.5 \mathrm{~m}$ above the animals and wind speed (WV) which was registered in triplicate using an anemometer. Relative humidity $(\mathrm{RH})$ was calculated from TDB and TWB using a psychrometric table. The temperature humidity index (THI) was determined as in Kelly and Bond (1971):

$T H I=T D B+(0.36 \times T W B)+41.5$

where: TDB $=$ dry bulb temperature $\left({ }^{\circ} \mathrm{C}\right) ;$ TWB $=$ wet bulb temperature $\left({ }^{\circ} \mathrm{C}\right)$.

Daily thermal amplitude was calculated from the difference between lowest and highest daily temperatures at time of measurement of the animals. Thermal radiation load (TRL in $\mathrm{Wm}^{-2}$ ) was calculated as:

$T R L=\sigma(M R T)^{4}$

$\mathrm{MRT}=$ mean radiant temperature $(\mathrm{K})$

$M R T=\left[\frac{h_{G}\left(T_{G}-T_{A}\right)+\varepsilon_{G} \sigma T_{G}^{4}}{\varepsilon_{G} \sigma}\right]^{\frac{1}{4}}$

Where: $\mathrm{h}_{\mathrm{G}}\left(\mathrm{W} \cdot \mathrm{m}^{-2} \cdot \mathrm{K}^{-1}\right)=$ is the convection coefficient of the black globe calculated as $=8.3 \times\left(\mathrm{WV}^{0.6}\right)$ - where $\mathrm{WV}=$ wind velocity $\left(\mathrm{m} . \mathrm{s}^{-1}\right) ; T_{G}(\mathrm{~K})=$ is the temperature of the black globe; $T_{A}(\mathrm{~K})=$ is the air temperature; $\varepsilon_{G}=0.95$ is the emissivity of the black globe; $\sigma=5.67 \times 10^{-8} \mathrm{~W} \cdot \mathrm{m}^{-2} \cdot \mathrm{K}^{-4}$ is the Stefan-Boltzman constant.

Table 1 Means and standard deviations (SD) of climate measures during heat tolerance experiment with sheep

\begin{tabular}{lllll}
\hline & Mean & SD & Minimum & Maximum \\
\hline$T_{\min }\left({ }^{\circ} \mathrm{C}\right)$ & 8.9 & 0.3 & 8.4 & 9.2 \\
$T_{\max }\left({ }^{\circ} \mathrm{C}\right)$ & 26.5 & 0.7 & 25.3 & 27.4 \\
RH $(\%)$ & 49.1 & 11.8 & 31.0 & 68.0 \\
WV $\left(\mathrm{ms}^{-1}\right)$ & 1.6 & 1.3 & 0.1 & 3.3 \\
THI & 69.9 & 2.1 & 66.4 & 72.6 \\
TRL $\left(\mathrm{Wm}^{-2}\right)$ & 219.9 & 118.5 & 80.0 & 381.0 \\
\hline
\end{tabular}

$T_{\min }$ minimum daily temperature, $T_{\max }$ maximum daily temperature, $R H$ air relative humidity, $W V$ wind speed, $T H I$ temperature humidity index, TRL thermal radiation load 
Thirty six lambs, 18 male and 18 female (4-5 months of age), weighing on average $22.03 \pm 2.1 \mathrm{~kg}$, from three genetic groups: Santa Inês (SI) and crosses Ile de France x Santa Inês (ILxSI) and Texel x Santa Inês (TxSI) were used. All lambs had been weaned for at least one month, individually identified, dewormed and received coast-cross (Cynodon dactylon) hay ad libitum, commercial mineral mixture and water ad libtum as well as concentrate feed at 8 and $16 \mathrm{~h}$, with $10 \%$ leftovers.

Animals were measured twice a day (at 6 and $14 \mathrm{~h}$ ) on 3 days with interval between collections of 6 days. Between the two collections (morning and afternoon), animals were kept in the sun with ad libitum access to clean water. The parameters evaluated on the lambs (using the methodology described in Silva 2000) were: rectal temperature (RT) using a thermometer, skin temperature (TS) using infrared thermometer $\left(\right.$ Raytek $\left.^{\mathrm{TM}}\right)$, temperature gradient rectal to skin (TRTS), temperature gradient air to skin (TSTDB), respiratory rate (RR), heart rate (HR), and sweating rate (SW).

Blood was collected by venipuncture using vacutainer ${ }^{\circledR}$ tubes with EDTA when the physiological traits were measured. The number of erythrocytes (HEM), leukocytes (LEU), and the concentration of hemoglobin $(\mathrm{Hb})$ were carried out in a semi-automatic cell counter (CC550, Cellm $\left.{ }^{\mathrm{TM}}\right)$. The hematimetric parameters (mean corpuscular volume$\mathrm{MCV}$, mean corpuscular hemoglobin concentration- $\mathrm{MCHC}$ and mean corpuscular hemoglobin- $\mathrm{MCH}$ ) were determined by calculation. Packed cell volume (PCV in \%) was determined using capillary tubes in microhematocrit centrifuge based on the technique described by Wintrobe (1976). The concentration of Total Plasma Proteins (TPP in g/100 mL) was determined using a refractometer and the plasma retained in a capillary tube. All the above measurements were considered physiological measurements.

The physical measurements included size measurements on the animals at the beginning of the experiment: shoulder height (AC), thoracic perimeter (PT), back (CD), and body (CC) lengths. Other traits included skin pigmentation (REF) using Wheatstone bridge (Silva 2000), skin thickness (ST) with an adipometer, coat thickness (CT), number of hairs per $\mathrm{cm}^{2}(\mathrm{NH})$, and hair length (HL; more details in Corrêa et al. 2012). Body surface area (SC) was calculated based on the formula for total cylinder area. The animals were weighed on collection days and daily weight gain (GMD) during the experimental period (which lasted 3 weeks) was calculated. Basal metabolic rate (TM) was calculated using:

$\mathrm{TM}(\mathrm{mg} / \mathrm{kcal})=\mathrm{aM}^{3 / 4}$

Where: $\mathrm{M}=$ mass of the animal in $\mathrm{kg} ; \mathrm{a}=70$ (Pachaly 2006).

Statistical tests included multivariate multiple regression, clustering, discriminant, and canonical analysis, according to Sneath and Sokal (1973) to assess the degree of similarity between the animals and verify the discriminatory capacity of the original traits in the formation of groups using canonical variables. The relative importance of canonical variables was measured by their eigenvalues (variances). All physical and physiological traits were used in the canonical analyses which were carried out by period (morning and afternoon). The canonical analysis used the physical variables to predict the physiological variables. Canonical redundancy analysis (RDA) was used to assess the variable inflation and the correlation between physical and physiological variables. TM and SC had high inflation factors $(>800)$ and were removed from the analyses. All other variance inflation factors were less than 5 -the highest being 4.2 for $\mathrm{CD}$. In the morning period no canonical correlations were significant and these are not presented. In the afternoon, ten canonical correlations were generated but only the first three $(P<0.05)$ explained sufficient variation to be included in further analyses. A discriminatory analysis was carried out to see which traits differed between the genetic groups. Analyses were performed in the statistical program SAS ${ }^{\circledR}$ v.9.3 (Statistical Analysis System, Cary, North Carolina) using the CLUSTER, STEPDISC, CANCORR, and DISCRIM procedures.

\section{Results and discussion}

Analysis of variance and correlations between these traits are discussed in Correa et al. (2012). The crossbred lambs were more similar to each other than to the Santa Inês lambs (Fig. 1). This fact is probably due to two factors: the $1 / 2$ bred animals have a common dam breed and the sire breeds used (Texel and Ile de France) have the Leicester breed as a common ancestor. The proximity observed between all genetic groups may be due to use of the SI as a maternal breed.

In general, individual TxSI animals separated themselves from animals from other groups, and while there was a greater overlap between the SI and ILxSI, it was still possible to separate a part of the ILxSI animals (Fig. 2). This fact can be justified by the analysis of the adaptive traits (Correa et al. 2012), which showed that TxSI had lower adaptation to heat than the other two groups. Within these two groups there was little difference, but on average the SI group was better adapted to conditions of Brasília, which agrees with the study of McManus et al. (2009) in which the SI breed was best suited in this region when compared with Bergamasca and their crossbreds. The canonical analysis showed that, by grouping individuals within breeds, the animals had variation in the characteristics of adaptation to heat.

In the cooler hours, the characteristics TS, CT, HL, RT, PT, and HEM helped to separate genetic groups. Animals with greater insulation (TxSI) were better adapted in these conditions. In the afternoon, in the hottest hours, the 


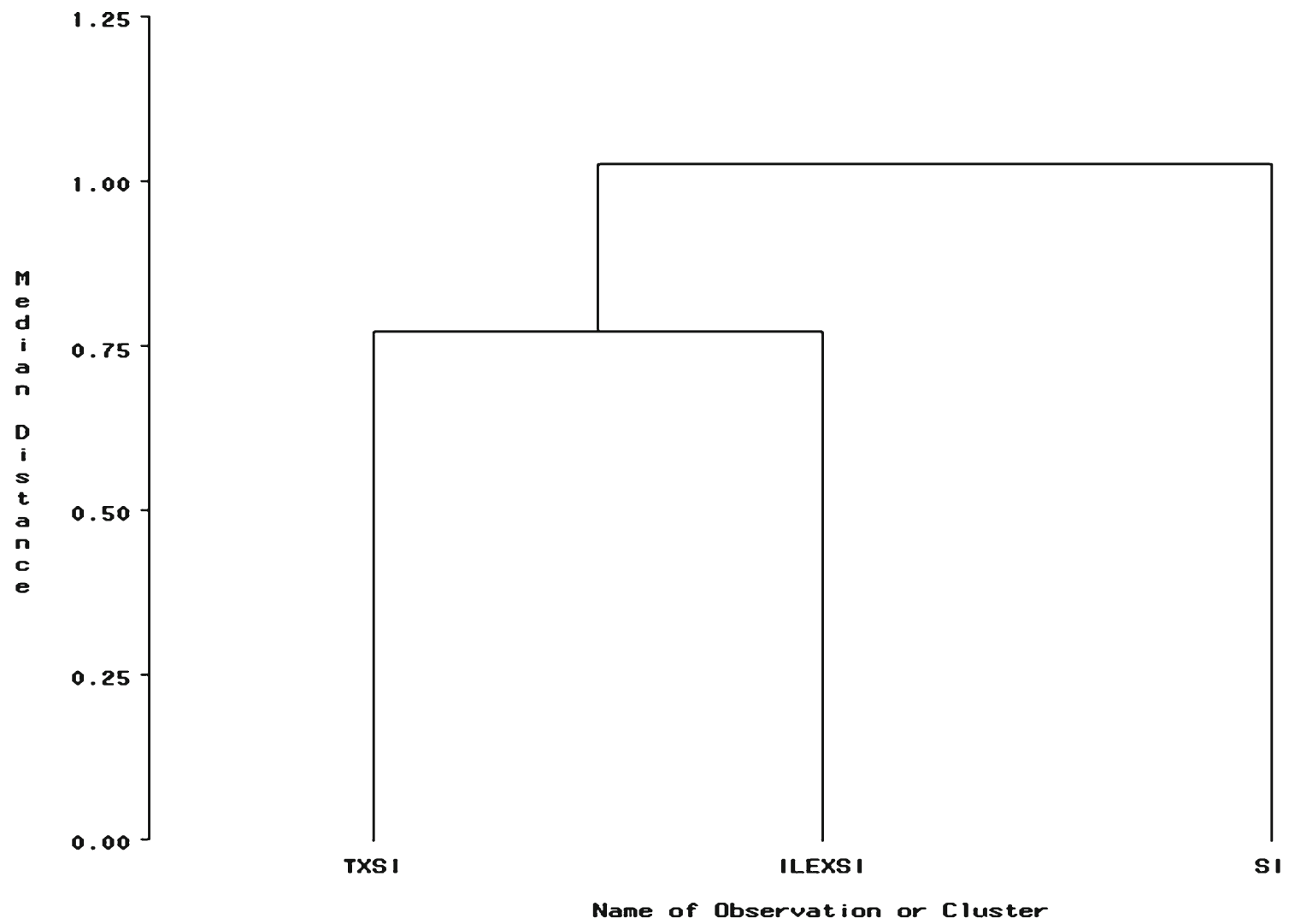

Fig. 1 Dendrogram between the three genetic groups of lambs evaluated for heat tolerance in the Federal District, Brazil. TxSI Texel x Santa Inês, IlxSI Ile de France x Santa Inês, SI Santa Inês

characteristics that helped to separate genotypic groups were ST, CT, HL, and MCHC. TxSI lambs, due to the greater insulation were more poorly adapted than ILxSI and SI, which showed better performance with lower values of HR. Ile de France and Texel are wool breeds with long and dense wool. However the hair breed Santa Inês is characterized by presenting short and glossy coat, and adaption to tropical conditions are related to the coat of this breed
(McManus et al. 2011b). As the crossbred genotypes exhibit characteristics of both parental breeds, it is likely that under these conditions, the adaptive characteristics to the heat of SI and Ile de France had a higher complementarity.

The canonical correlations of physical and physiological variables (Table 2) showed that the traits that explained most of the differences between the physiological variables were $\mathrm{AC}(r=0.57)$ and GMD $(r=0.83)$. Insulation and skin
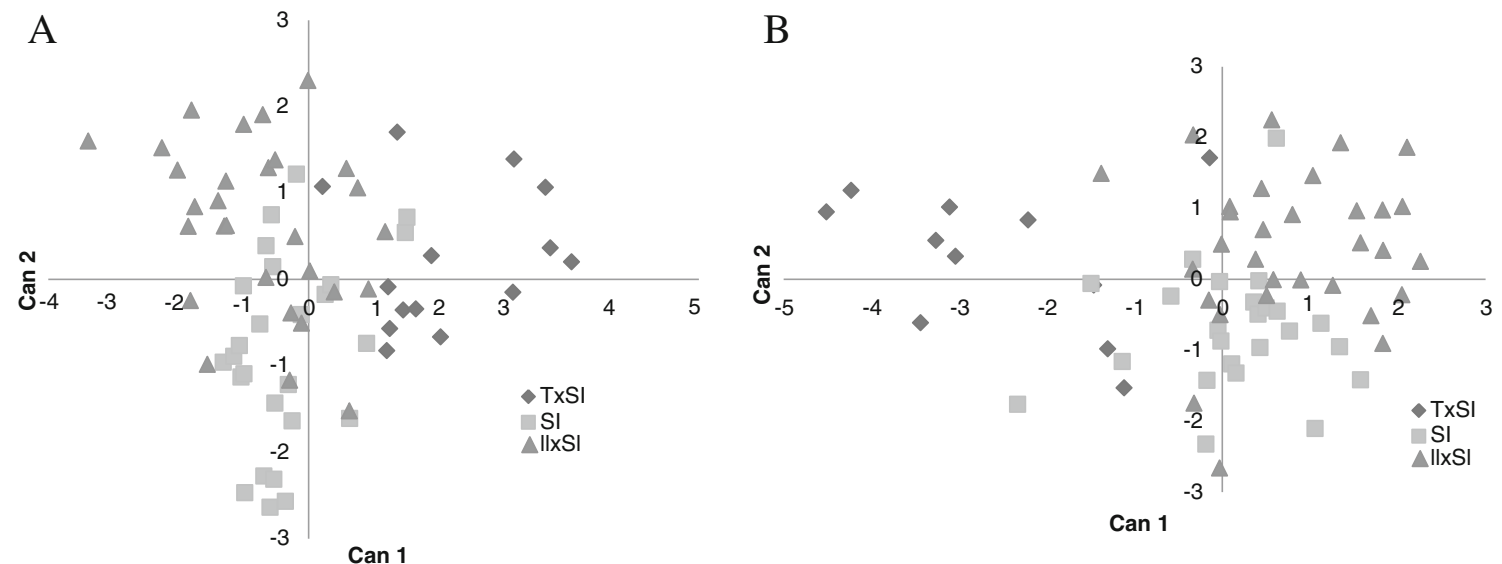

Fig. 2 Canonical representation of individual means for traits associated with heat tolerance for genetic groups of lambs in the morning (a) and afternoon (b). TxSI Texel x Santa Inês, IlxSI Ile de France x Santa Inês, SI Santa Inês 
Table 2 Canonical correlations of physical traits used to explain variation in physiological canonical traits

\begin{tabular}{|c|c|c|c|c|c|c|}
\hline \multirow[t]{2}{*}{ Traits } & \multicolumn{3}{|c|}{ Standardized canonical coefficients } & \multicolumn{3}{|c|}{ Canonical correlations } \\
\hline & V1 & V2 & V3 & V1 & V2 & V3 \\
\hline REF & -0.42 & -0.10 & 0.24 & -0.36 & -0.09 & 0.26 \\
\hline ST & -0.38 & 0.79 & 0.24 & -0.22 & 0.14 & 0.15 \\
\hline $\mathrm{CT}$ & 0.48 & -0.98 & -0.08 & 0.10 & -0.27 & 0.23 \\
\hline HL & 0.14 & -0.90 & 0.13 & 0.25 & -0.54 & -0.03 \\
\hline NH & -0.17 & 0.29 & -0.81 & 0.03 & 0.01 & -0.71 \\
\hline GMD & 0.54 & 0.62 & 0.31 & 0.83 & 0.22 & 0.03 \\
\hline $\mathrm{CD}$ & -0.15 & 0.59 & 0.62 & 0.18 & 0.09 & 0.27 \\
\hline $\mathrm{CC}$ & 0.05 & -0.38 & -0.29 & 0.10 & 0.09 & 0.02 \\
\hline $\mathrm{AC}$ & 0.47 & -0.22 & -0.35 & 0.57 & 0.22 & -0.21 \\
\hline PT & 0.15 & 0.27 & 0.26 & -0.02 & 0.08 & 0.39 \\
\hline$R^{2}$ & 0.52 & 0.41 & 0.32 & & & \\
\hline$\%$ of variation & 41 & 29 & 16 & & & \\
\hline
\end{tabular}

properties had low and negative canonical correlations with physiological traits $(\mathrm{ST}=-0.22 ; \mathrm{REF}=-0.36)$. The second correlation shows importance for traits such as HL and CT. The larger animals were more efficient in the use of physiological mechanisms of adaptation, with greater weight gains and less insulation. When animals have more insulation, conferred by thicker and denser coats, they have greater restrictions to cutaneous evaporation and therefore it becomes more difficult to respond to the heat challenge (Silva 2000; Pereira 2005).

The largest canonical correlations between the tolerance and physical traits were with PCV $(r=0.61)$, HR $(0.28)$, MCHC (-0.37), and ST (-0.38). The second canonical correlation shows the importance of traits such as TRTS, RR, Hb, and HEM (Table 3).
The first two autovectors (Fig. 3) explained $94 \%$ of the variation available. Animals with high metabolic rates grew faster and had higher SC, RT, RR, and HR. The higher the body mass of the animal, the lower proportion of surface contact available for heat loss (Silva 2000). Increased WV increases convective heat loss by increasing evaporative exchange between body and the environment which ultimately reduces the RT. The heat losses by convection are increased with an increase in WV, facilitating heat loss from the body of the animal to the environment and increasing evaporative exchanges, to reduce RT. This agrees with Cena and Monteith (1975), who found that heat transfer attributed to conduction throughout the coat is not as significant as free convection and radiation exchange between the hairs, which are most responsible for heat transfer through the coat when WV is low.
Table 3 Canonical correlations between variables of tolerance and physical characteristics (W1, W2, W3) in the afternoon
$H R$ heart rate, $R R$ respiratory rate, $R T$ rectal temperature, $H E M$ erythrocytes, $H b$ hemoglobin, $P C V$ packed cell volume, $T P P$ total plasma protein, $M C V$ mean corpuscular volume, $\mathrm{MCH}$ mean corpuscular hemoglobin, $\mathrm{MCHC}$ mean corpuscular hemoglobin concentration, $S W$ sweating rate, TRTS temperature gradient rectal to skin, TSTDB temperature gradient air to skin

\begin{tabular}{|c|c|c|c|c|c|c|}
\hline & \multicolumn{3}{|c|}{ Standardized canonical coefficients } & \multicolumn{3}{|c|}{ Canonical correlations } \\
\hline & $\mathrm{W} 1$ & W2 & W3 & W1 & W2 & W3 \\
\hline HR & 0.19 & -0.57 & 0.20 & 0.28 & -0.09 & -0.06 \\
\hline $\mathrm{RR}$ & 0.22 & 0.70 & -0.33 & 0.19 & 0.44 & -0.30 \\
\hline RT & -0.13 & 0.16 & -0.15 & 0.13 & 0.15 & -0.17 \\
\hline HEM & -0.80 & -0.35 & 0.38 & -0.19 & -0.37 & 0.23 \\
\hline $\mathrm{Hb}$ & 0.33 & 0.51 & 4.32 & -0.18 & 0.33 & 0.43 \\
\hline PCV & 0.92 & -0.00 & 0.27 & 0.61 & 0.27 & 0.29 \\
\hline ТPP & -0.15 & -0.51 & -0.25 & -0.23 & -0.26 & -0.22 \\
\hline $\mathrm{MCV}$ & -0.60 & 3.38 & 1.20 & 0.23 & 0.14 & 0.10 \\
\hline $\mathrm{MCH}$ & -1.75 & -3.73 & -9.58 & -0.05 & 0.30 & 0.08 \\
\hline $\mathrm{MCHC}$ & 0.21 & -0.00 & 3.12 & -0.37 & 0.09 & 0.08 \\
\hline SW & 1.63 & 0.34 & 8.19 & 0.05 & 0.21 & -0.10 \\
\hline ST & -0.87 & 2.79 & -1.74 & -0.38 & 0.29 & -0.03 \\
\hline TRTS & 0.81 & 0.15 & -0.05 & 0.24 & 0.43 & -0.30 \\
\hline TSTBS & 0.19 & -0.57 & 0.20 & -0.05 & -0.31 & 0.16 \\
\hline
\end{tabular}




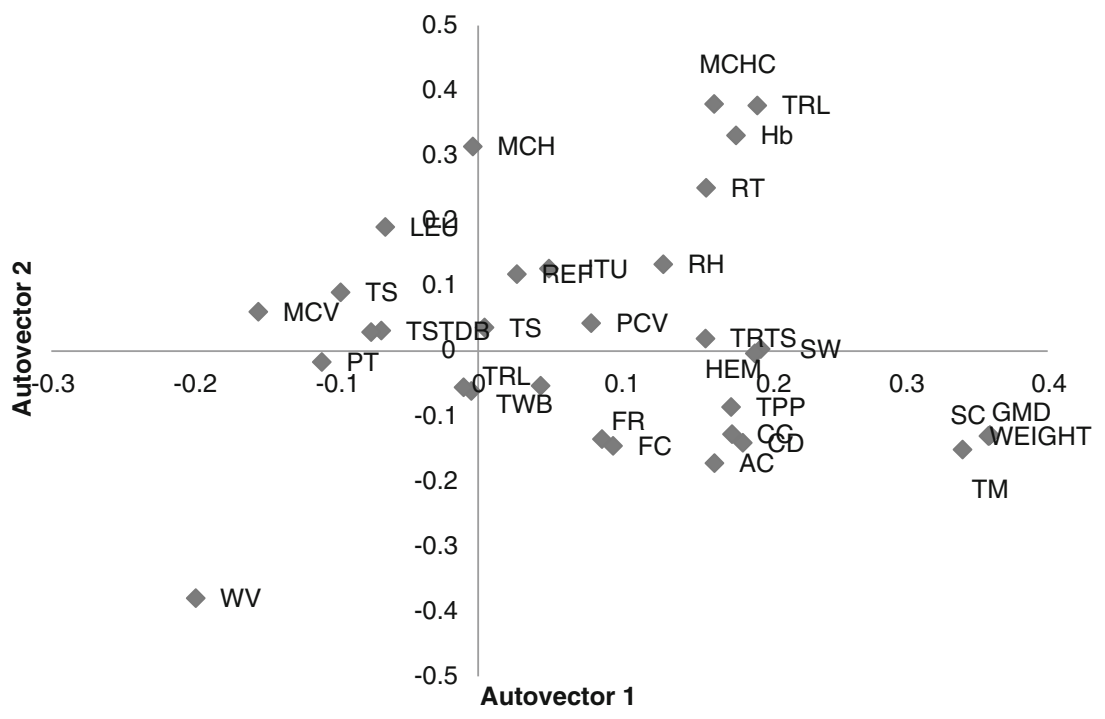

Fig. 3 First two eigenvectors of physical and physiological characteristics of lambs Santa Inês $(S I)$, and crossbred Ile de France x Santa Inês $(I L x S I)$ and crossbred Texel x Santa Inês $(T x S I)$ in Federal District. $H R$ heart rate, $R R$ respiratory rate, $T S$ skin temperature, $R E F$ color of skin pigmentation by reflectance, $S W$ sweating rate, $P C V$ packed cell volume, TPP total plasma protein, $M C V$ mean corpuscular volume, $L E U$ total leukocytes, $H E M$ erythrocytes, $H b$ hemoglobin, $M C H$ mean corpuscular hemoglobin, $M C H C$ mean corpuscular hemoglobin

However, this depends on the amount of movement and direction at which the wind hits the animal's body surface, when convection may become more important.

Higher values of TRL were accompanied by increasing RT, RR, and HR, as well as higher TRTS (Fig. 3). This is probably due to the heat load generated by increased levels of radiation and humidity which, in turn, create discomfort for the animals by hindering the loss of sensible and latent heat, causing physiological reactions such as compensatory increase in RR and HR to help reduce the increase in RT. This agrees with Quesada et al. (2001) who found that when the rectal temperature increased due to the joint action of environmental effects, respiratory and cardiac frequencies also increased. Thus, the greater the difference between rectal and skin temperature, translated into high TRTS, the greater the thermal discomfort and lower the animal's thermoregulatory capacity due to the increased insulation (CT, $\mathrm{NH}$ ) thus increasing RT, and leading to increased RR, HR, and heat stress. This agrees with Santos et al. (2006) who reported that high temperature and humidity in the animal is impaired by the difficulty in heat dissipation due to small differences between surface and environmental temperatures. This explains the increase in rectal temperatures (heat buildup) and high respiratory frequency.

Breed groups were separated by animal size, with larger animals growing faster and had thinner coats with lower reflectance (Fig. 4). Thicker coats were accompanied by higher $\mathrm{MCH}$ and lower HEM, indicating more stress. concentration, $T D B$ dry bulb temperature, $R H$ relative humidity, $W V$ wind speed, $T H I$ temperature and humidity index, $T R L$ thermal radiation load, TRTS temperature gradient rectal to skin, TSTDB temperature gradient air to skin, $S T$ skin thickness, $C T$ coat thickness, $H L$ hair length, $N H$ number of hairs per $\mathrm{cm}^{2}, G M D$ average daily weight gain, $C D$ back length, $C C$ body length, $P T$ thoracic perimeter, $S C$ body surface area, $T M$ basal metabolic rate, $A C$ shoulder height, $R T$ rectal temperature, $T W B$ wet bulb

Skin and coat traits were important in separating the groups (not shown), in agreement with Castanheira et al. (2010a) in adult sheep. These variables have been shown to be related to heat tolerance in other studies such as Silva (2000) and Pereira (2005), where animals with thicker hairs and denser coats have more difficulty in releasing heat. The different genetic groups differed in terms of coat and skin thickness and hair length. Although there were no significant differences between genetic groups for weight, the shape of the animals differed; therefore, body measurements such as AC, body score and PT differed between groups. These differences led to different physiological responses to heat. These traits were important for differentiating the genetic groups (Table 4), with heart rate and MCV being more important in the morning and $\mathrm{RR}, \mathrm{PT}$, and SW more important in the afternoon. This is in contrast to Castanheira et al. (2010a) who found that heart rate, sweating rate and mean corpuscular volume did not show much discriminatory value in adult sheep. This may reflect changes in physiology between adult and young animals. MCV defines the mean size of a red cell in the animal blood and is used to classify anemia in animals (Jain 1993). The SI had higher MCV in the morning than the other groups, possibly reflecting better adaption to other factors including nutrition and disease stresses not evident here. Heart rate may be affected by other factors as well as temperature, such as management stress, thereby possibly reflecting that the Texel cross animals were less stressed by these other factors than the other genetic groups. 


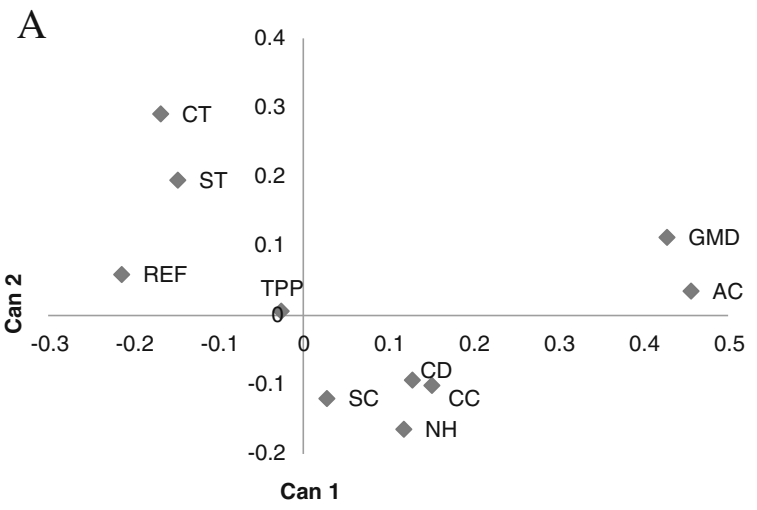

Fig. 4 Canonical averages for a physical and $\mathbf{b}$ physiological adaptation to heat in lambs in the DF. $T S$ skin temperature, $R E F$ color of skin pigmentation by reflectance, $P C V$ packed cell volume, $M C V$ mean corpuscular volume, $L E U$ total leukocytes, $H b$ hemoglobin, $M C H C$ mean corpuscular hemoglobin concentration, TSTDB temperature gradient air to skin, $S T$ skin thickness, $N H$ number of hairs per $\mathrm{cm}^{2}, G M D$

The higher respiratory rate of TxSI animals in the afternoon reflects their lower tolerance to heat stress and made them different from the other genetic groups. SI had lower TPP than the other animals. This is probably a reflection of splenic contraction due to the liberation of epinephrine in the crossbred animals which normally occurs $60 \mathrm{~min}$ after exposure to the stress factor (Paludo et al. 2002).

$\mathrm{MCHC}, \mathrm{MCV}$, and $\mathrm{MCH}$ are calculated using PCV and HEM. Low MCV can be caused by poor diet, blood loss, or chronic disease. MCHC is a measure of the concentration of hemoglobin in a given volume of packed red blood cells. The blood traits such as number of leuckocytes and red blood cells as well as total plasma protein may be altered by dehydration caused by the increased breathing rate according to Hodgson and Hodgson (2002).

The error rate for allocation of animals within the genetic groups using the discriminant functions depended on the traits used (Table 4), where more than $90 \%$ of each group was correctly allocated in their corresponding genetic group using all traits. Errors occurred in the allocation of animals

Table 4 Discriminating traits between genetic groups of lambs

\begin{tabular}{lll}
\hline & TxSI & ILxSI \\
\hline Afternoon & & \\
SI & RR, SW, PT & HEM, PT, SW, MCH \\
TxSI & & RR, MCH \\
Morning & & \\
SI & MCV, HR & RT, MCV \\
TxSI & & HR, MCHC
\end{tabular}

$R R$ respiratory rate, $S W$ sweating rate, $P T$ thoracic perimeter, $M C V$ mean corpuscular volume, $H E M$ erythrocytes, $M C H$ mean corpuscular hemoglobin, $R T$ rectal temperature, $M C H C$ mean corpuscular hemoglobin concentration, $H R$ heart rate

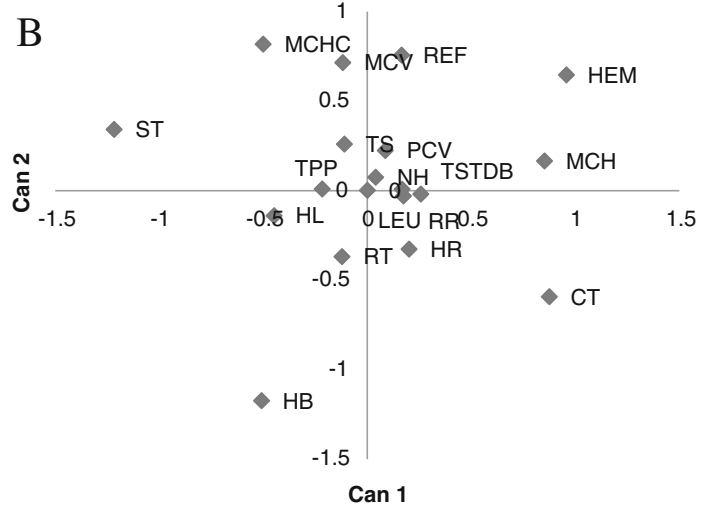

average daily weight gain, $C D$ back length, $C C$ body length, $A C$ shoulder height, $R T$ rectal temperature, $T P P$ concentration of total plasma proteins, $M C H$ mean corpuscular hemoglobin, $C T$ coat thickness, $H L$ hair length, $H E M$ erythrocytes, $S C$ body surface area, $R R$ respiratory rate, $H R$ heart rate

in the group ILxSI with SI and vice versa. These two groups differ little in heat adaptation, while TxSI were less well adapted to these environmental conditions.

When only physical traits were used, more than $62 \%$ of ILxSI and SI groups were properly allocated in their corresponding genetic group, and $97.22 \%$ of TxSI. This is probably due the fact that this group was composed of animals less adapted to these environmental conditions.

The errors were larger when allocating animals into their genetic groups using the physiological characteristics. This probably occurred because the animals evaluated in this phase had not yet fully developed their coats, with the presence of fluff covering some animals of all genetic groups, leading to

Table 5 Percentages of error for discriminant analyses using different traits to separate sheep groups

\begin{tabular}{llll}
\hline Genetic group & ILxSI & SI & TxSI \\
\hline \multicolumn{2}{l}{ Physical and physiological } & & \\
IlxSI & 90.91 & 9.09 & 0.00 \\
SI & 7.84 & 92.16 & 0.00 \\
TxSI & 0.00 & 0.00 & 100.00 \\
Error & 0.09 & 0.08 & 0.00 \\
Physical & & & \\
IlxSI & 69.44 & 23.61 & 6.94 \\
SI & 16.67 & 62.96 & 20.37 \\
TxSI & 0.00 & 2.78 & 97.22 \\
Error & 0.31 & 0.37 & 0.03 \\
Physiological & & & \\
IlxSI & 43.94 & 27.27 & 28.79 \\
SI & 28.30 & 47.17 & 24.53 \\
TxSI & 24.14 & 20.69 & 55.17 \\
Error & 0.56 & 0.53 & 0.45 \\
\hline
\end{tabular}

IlxSI Ile de France x Santa Ines, SI Santa Ines, TxSI Texel x Santa Ines 
greater uniformity of physical data. Physiological characteristics that differed least between the animals were HR and RR. According to Castanheira et al. (2010a), physiological variables (HR, RR) are excellent indicators of health status in sheep, but they must be properly interpreted, as they may be influenced by species, age, exercise, and excitement.

The error rate allocation within the genetic group using the discriminant functions for each group reached $51 \%$ (Table 5) using physiological characteristics. This pattern is a reflection of the inter-relationships between physiological and physical traits.

\section{Conclusion}

Multivariate analysis was effective in separating genetic groups of lambs using physical and physiological parameters. The physical and physiological traits effective in separating the genotypes during the cooler hours (morning) were skin and coat thickness, body length, rectal temperature, thoracic perimeter, and number of red blood cells. In hotter hours (afternoon), traits used in differentiating animals included skin and coat thickness, heart rate, respiratory rate, and mean corpuscular hemoglobin concentration. The physical variables were more efficient than the physiological in separating the animals into heat tolerance groups.

Acknowledgments Thanks to CAPES for scholarships, FAPDF and CNPq (INCT Pecuária) for financing the project.

\section{References}

ANUALPEC, 2012. Pork Production and Other Animals. In: Anuário da Pecuária Brasileira, (AgraFNP, São Paulo), 306-307.

Castanheira, M., Paiva, S.R., Louvandini, H., Landim, A.V., Fioravanti, M.C.S., Dallago, B.S., Correa, P.S., McManus, C., 2010a. Use of heat tolerance traits in discriminating between groups of sheep in central Brazil, Tropical Animal Health and Production, 42, 1821-1828.

Castanheira, M., Paiva, S.R., Louvandini, H., Landim, A.V., Fioravanti, M.C.S., Dallago, B.S., Correa, P.S., McManus, C., 2010b. Multivariate analysis for characteristics of heat tolerance in horses in Brasil, Tropical Animal Health and Production, 42, 185-191.

Cena, K., Monteith, J.L., 1975. Transfer processes in animal coats. II. Conduction and convection, Proceedings of the Royal of Society London B: Biological Sciences, 88, 395-411.

Correa, M.P.C., Cardoso, M.T., Castanheira, M., Landim, A.V., Dallago, B.S.L., Louvandini, H. McManus, C., 2012. Heat tolerance in three genetic groups of lambs in central Brazil, Small Ruminant Research, 104, 70-77.

Dias, L.A.S., Kageyama, P.Y., Castro, G.C.T., 1997. Divergência genética multivariada na preservação de germoplasma de cacau (Theobromacacao L.), Revista Agrotrópica, 9, 29-40.

Ferreira, C.A., Ferreira, R.L.C., Santos, D.C., Santos, M.V.F., Silva, J.A.A., Lira, M.A., Molica, S.G., 2003. Utilização de técnicas multivariadas na avaliação da divergência genética entre clones de palma forrageira (Opuntiaficus-indica mill.), Revista da Sociedade Brasileira de Zootecnia, 32, 1560-1568 (Supl. 1).
Hodgson, J.L., Hodgson, D.R., 2002. Inflammatory Airway Disease, In: Lekeux, P. (ed), Equine Respiratory Diseases, Ithaca, 2002, (International Veterinary Information Service, New York). Available in: <http://www.ivis.org/special_books/lekeux/hodgson/ivis.pdf>. Retrieved on December 14, 2012.

Jain, N.C., 1993. Evaluation of Anemias and Polycythemias. In: Jain, N.C. (ed), Essentials of Veterinary Hematology, 1993, (Williams \& Wilkins, Philadelphia), 158-168.

Kelly, C.F., Bond, T.E., 1971. Bioclimatic factors and their measurement. In: Kelly, C. F. and Bond, T.E. (eds), A guide to environmental research on animals. 1st ed. (National Academy of Sciences: Washington).

Marai, I., El-Darawany, A., Fadiel, A., Abdel-Hafez, M., 2007. Physiological traits as affected by heat stress in sheep - A review, Small Ruminant Research, 71, 1-12.

McManus, C., Teixeira, R.A., Dias, L.T., Louvandini, H., Oliveira, E.M.B., 2008. Características produtivas e reprodutivas de vacas Holandesas e mestiças Holandesas x Gir no Planalto Central, Revista Brasileira de Zootecnia, 37, 819-823.

McManus, C.M., Paludo, G.R., Louvandini, H., Gugel, R., Sasaki, L.C.B., Paiva, S.R., 2009. Heat tolerance in Brazilian sheep: physiological and blood parameters, Tropical Animal Health and Production, 9, 95-101.

McManus, C., Paiva, S.R., Oliveira, R.O., 2010. Genetics and breeding of sheep in Brazil. Revista Brasileira de Zootecnia, 39, 236-246.

McManus, C., Castanheira, M., Paiva, S.R., Louvandini, H., Fioravanti, M.C.S., Paludo, G.R., Bianchini, E.M., Corrêa, P.S., 2011a. Use of multivariate analyses for determining heat tolerance in Brazilian Cattle. Tropical Animal Health and Production, 43, 623-630.

McManus, C., Louvandini, H., Gugel, R., Sasaki, L.C.B., Oliveira, E.M.B., Bernal, F.E.M., Paiva, S.R., Paim, T.P., 2011b. Skin and coat traits in sheep in Brazil and their relation with heat tolerance, Tropical Animal Health and Production, 43, 121-126.

Neiva, J.N.M., Teixeira, M., Turco, S.H.N., Oliveira, S.M.P., Moura, A.A.N., 2004. Efeito do estresse climático sobre parâmetros produtivos e fisiológicos de ovinos Santa Inês mantidos em confinamento na região litorânea do Nordeste do Brasil, Revista Brasileira de Zootecnia, 33, 668-678.

Pachaly, J.R., 2006. Terapêutica por extrapolação alométrica. In: Cubas, Z.S., Silva, J.C.R., Catão-Dias, J.L. (eds), Tratado de Animais Selvagens: Medicina veterinária (Roca, São Paulo).

Paludo, G.R., McManus, C., Melo, R.Q., Cardoso, A.G., Melo, F.P.S., Moreira, M., Fuck, B., 2002. Effect of heat stress and exercise on physiological parameters of horses of the Brazilian army, Revista Brasileira de Zootecnia, 31, 1130-1142.

Pereira, J.C.C., 2005. Fundamentos de bioclimatologia aplicados à produção dos animais domésticos, (FEPMVZ, Belo Horizonte).

Quesada, M., McManus, C., Couto, D’araújo, F.A., 2001. Tolerância ao calor de duas raças de ovinos deslanados no Distrito Federal, Revista Brasileira de Zootecnia, 30, 1021-1026 (Suplemento 1).

Santos, J.R.S., Souza, B.B., Souza, W.H., Cezar, M.F., Tavares, G.P., 2006. Respostas fisiológicas e gradientes térmicos de ovinos das raças Santa Inês, Morada Nova e seus cruzamentos com a raça Dorper às condições do semi-árido nordestino, Ciências Agrotecnologia, 20, 995-1001.

Silanikove, N., 2000. Effects of heat stress on the welfareof extensively managed domestic ruminants, Livestock Production Science, 67, 1-18 (suppl. 1).

Silva, G.R., 2000. Introdução à bioclimatologia animal, (Nobel, São Paulo). Sneath, P.H., Sokal, R.R., 1973. Numerical taxonomy: The principles and practice of numerical classification, (W.H. Reeman, San Francisco).

Starling, J.M.C., Silva, R.G., Negrão, J.A., Maia, A.S.C., Bueno, A.R., 2005. Variação Estacional dos hormônios tireoideanos e do cortisol em ovinos em ambiente tropical, Revista Brasileira de Zootecnia, 34, 2064-2073.

Wintrobe, M.M., 1976. Clinical hematology, (Lea \& Febiger, Philadelphia). 